\title{
Cysts and nauplii biometry characteristics of seven Artemia franciscana (Kellog, 1906) populations from Mexico
}

\author{
Características biométricas de quistes y nauplios de siete poblaciones de \\ Artemia franciscana (Kellog, 1906) de México \\ Jorge Castro $^{1}$, Thalía Castro ${ }^{1}$, Jesús Sánchez ${ }^{1}$, Germán Castro ${ }^{1}$, Araceli Castro ${ }^{1}$, \\ Juana Zaragoza ${ }^{1}$, Ramón de Lara ${ }^{1}$ and Maria del C. Monroy ${ }^{1}$ \\ ${ }^{1}$ Universidad Autónoma Metropolitana-Xochimilco, Live Food Production Laboratory. El Hombre y su Ambiente \\ Calzada del Hueso $N^{\circ} 1100$. Colonia Villa Quietud. Mexico, 04960, D.F. \\ camj7509@correo.xoc.uam.mx
}

\begin{abstract}
Resumen.- El objetivo del presente trabajo fue establecer las características de quistes y nauplios de siete poblaciones de Artemia de México, cubriendo los aspectos relacionados con el diámetro del quiste normal y descapsulado, grosor del corion y la longitud del nauplio. Los quistes empleados para el experimento fueron recolectados en su hábitat natural. Se efectuaron 100 mediciones para cada una de las variables con la ayuda de un microscopio óptico Olympus, equipado con una cámara fotográfica digital y un programa automático analizador de imágenes. Para determinar diferencias entre poblaciones, se realizó un análisis de varianza (ANOVA). Al encontrar diferencias significativas se efectuó la comparación de medias múltiples por el método de Tukey. En cuanto al diámetro de quistes, la técnica de Tukey demostró que no existían diferencias significativas entre los pares: Yavaros/Cuatro Ciénegas y Cuatro Ciénegas/Texcoco. Para el diámetro de quistes descapsulados, el mismo análisis no demostró diferencia significativa en Yavaros/Cuatro Ciénegas, Yavaros/Texcoco y Cuatro Ciénegas/Texcoco. Comparaciones entre la longitud del nauplio no demostraron diferencias entre Yavaros/Ohuira, Real Salinas/Cuatro Ciénegas y San Luis Potosí/Texcoco. Las poblaciones de Texcoco, San Luis Potosí, Yavaros y Ohuira tienen una longitud naupliar más pequeña que la población de la bahía de San Francisco y son recomendables estas poblaciones para la larvicultura, por lo que se consideran como posibles proyectos viables de cultivo en sus hábitats.
\end{abstract}

Palabras clave: Artemia, México, biometría, quistes, nauplios

\begin{abstract}
The goal of this study was to establish the biometric characteristics of cysts and nauplii of seven Artemia populations from Mexico, covering aspects related with the normal and decapsulated cysts diameter, chorion thickness, and nauplii instar I length. Cysts used for the experiment were collected in their natural habitat, cleaned, dried, and stored in the laboratory. One hundred measurements for each of the variables where done with an Olympus optical microscope equipped with a digital camera and an automated image analyzer program. To determine differences in the mean values of variables among populations, analysis of variance (ANOVA) was performed with post hoc Tukey pairwaise comparison tests. In hydrated cysts, Tukey's analysis showed no significant differences between the pairs: Yavaros/Cuatro Cienegas and Cuatro Ciénegas/Texcoco. For the diameter of decapsulated cysts the same analysis indicated no significant differences in Yavaros/Cuatro Ciénegas, Yavaros/Texcoco, and Cuatro Cienegas/Texcoco. Comparisons of naupliar lengths among Yavaros/Ohuira, Real Salinas/Cuatro Cienegas, and San Luis Potosi/Texcoco did not reveal differences. The Texcoco, San Luis Potosí, Yavaros, and Ohuira populations had smaller naupliar lengths than those of the San Francisco Bay populations. It is advisable to use these populations in larviculture and to consider their cultivation in their own habitats as possible viable projects.
\end{abstract}

Key words: Artemia, Mexico, biometry, cysts, nauplii

\section{Introduction}

The brine shrimp of the genus Artemia is a cosmopolitan crustacean that lives in coastal lagoons, inland salt waters, and solar saltworks (Persoone \&
Sorgeloos 1980). This genus is a complex group of species, superspecies, and mainly subspecies that are separated due to reproductive isolation (Browne \& Bowen 1991, Triantaphyllidis et al. 1998, Van Stappen 2002). The species of the genus Artemia present a wide 
repertoire in their adaptability processes intimately related to the survival of this organism in hypersaline habitats.

Knowledge of the biometrics of cysts and nauplii is important when these organisms are going to be used in aquaculture feeding (Van Stappen 1996). As known, the instar I and II nauplius stages are the most used in larviculture, since they are quickly obtained from the cysts. However, it must be considered that the quality of cysts hatching, the nutritional value, and energetic content of nauplii are relevant characteristics for their use in aquaculture (Van Stappen 2002).

The nutritional efficacy of an organism as feed is determined by its capacity to be digested by the prey and, hence, is correlated with its size and shape, which allows to classify the diverse Artemia populations; although these characteristics can vary among cyst batches, due to differences induced by environmental factors or factors related to the harvesting, processing, and drying of cysts. Other biological characteristics, such as: volume and dry weight of the cyst, length of the instar I and II nauplius, individual weight of the nauplius, as well as its volume and energetic content, are variables highly correlated with the cyst's diameter; therefore, the biometric parameters regarding the diameter of the cyst and size of the nauplius can be considered useful to characterize the diverse Artemia populations.

The size and volume of nauplii are very important features for feed, since offering nauplii of larger size and volume than the mouth opening of the prey could cause death by starving of the latter, as it is unable to ingest it, or the feed can become stuck in its mouth causing also its death. For example, in marine fish Menidia menidia larvae, a direct correlation between the size of the fed nauplii and mortality of larvae has been observed when supplying organisms larger than $520 \mu \mathrm{m}$ in length, inducing an over 50\% mortality during the first five days of life, while supplying nauplii smaller than $430 \mu \mathrm{m}$ allows reducing fish larvae mortality to below 10\% (Merchie 1996).

Léger et al. (1986) mentioned that the adequate size of nauplii $(<400 \mu \mathrm{m})$ to feed fish larvae will solve feeding and ingestion problems and will allow for a better selection of the cysts to be used in this activity or to propose other species, such as rotifers, that might favor a better feed ingestion by the prey, leading to the design of diets in which life feed is used according to the needs of the corresponding species.

The increasing demand of good quality cysts and adequate sized nauplii to serve as feed for the first life stages of cultured species has led several countries to search for wild Artemia populations or to perform inoculation programs at diverse sites (Camara 2004, Dhont \& Sorgeloos 2002).

To establish the quality and, consequently, the marketing price of Artemia cysts several parameters have been taken into account, among them are the size of the cysts and nauplii, which together with the hatching and nutritional qualities, provide the features for a higher or lower demand of the product.

Different studies with Artemia have been performed in Mexico: on its biometry (Castro et al. 1995, Castro et al. 1997a, 1997b, 1997c, Castro et al. 2000b, Castro 2004), Artemia interactions with its habitat (Castro et al. 1987a, 1987b), interbreeding studies with Artemia franciscana from San Francisco Bay (Castro et al. 1999) and with other Mexican populations (Gallardo \& Castro 1987, Castro et al. 1989), as well as aspects of nutritional quality in Artemia (Castro 1993, Castro et al. 1995, Castro et al. 2003, Malpica 2002).

Recently, studies being performed at the Live Food Production Laboratory of the Universidad Autonoma Metropolitana-Xochimilco demand better interpretation of biometrical data for studying cyst and naupliar characters and to compare them with those of other populations in the world. This investigation is focused on cyst and naupliar characters of seven Mexican Artemia populations trying to evaluate their potential use in aquaculture.

\section{Material and methods}

\section{Artemia populations}

The cysts of each population used in this study were collected in their natural habitat during the years 20022004. Cysts were cleaned and placed in a brine solution at $150 \mathrm{gL}^{-1}$ salinity, to be separated by density (Vinatea 1999). Afterwards, they were dried in an oven at $50^{\circ} \mathrm{C}$ during $24 \mathrm{~h}$ and were sieved through $300 \mu \mathrm{m}-$ mesh net, and stored at $-20^{\circ} \mathrm{C}$ until needed.

Sites and their geographical coordinates of the seven Artemia populations studied are shown in Table 1 and Fig. 1. 
Table 1

Sites and geographical coordinates of places in Mexico with natural Artemia populations studied in this work

Sitios y coordenadas geográficas de los lugares de México con poblaciones naturales de Artemia consideradas en este trabajo

\begin{tabular}{|c|c|c|c|}
\hline Name & State & Place & Geographical localization \\
\hline 1) Salina Tres Hermanos (YAV) & Sonora & Yavaros & $26^{\circ} 40^{\prime} \mathrm{N} ; 109^{\circ} 35^{\prime} \mathrm{W}$ \\
\hline 2) Bahía de Ohuira (OHUI) & Sinaloa & Ahome & $25^{\circ} 36^{\prime} \mathrm{N} ; 109^{\circ} 02^{\prime} \mathrm{W}$ \\
\hline 3) Juchitán (JUCH) & Oaxaca & Salinera del Istmo & $\begin{array}{l}16^{\circ}-16^{\circ} 39^{\prime} \mathrm{N} ; \\
94^{\circ} 45^{\prime}-95^{\circ} 06^{\prime} \mathrm{W}\end{array}$ \\
\hline 4) Real de las Salinas (R.SAL) & Campeche & Real de las Salinas & $20^{\circ} 02^{\prime} \mathrm{N} ; 90^{\circ} 14^{\prime} \mathrm{W}$ \\
\hline 5) Cuatro Ciénegas de Carranza (COAH) & Coahuila & Cuatro Ciénegas & $29^{\circ} 36^{\prime} \mathrm{N} ; 9^{\circ} 20^{\prime} \mathrm{W}$ \\
\hline 6) Salinas of Hidalgo (SLP) & San Luis Potosí & Salinas de Hidalgo & $22^{\circ} 39^{\prime} \mathrm{N} ; 101^{\circ} 43^{\prime} \mathrm{W}$ \\
\hline 7) Тexсосо (TEX) & Edo. Mexico & Ecatepec de Morelos & $19^{\circ} 32^{\prime} \mathrm{N} ; 99^{\circ} 00^{\prime} \mathrm{W}$ \\
\hline
\end{tabular}

Data: Castro et al. (2000b).

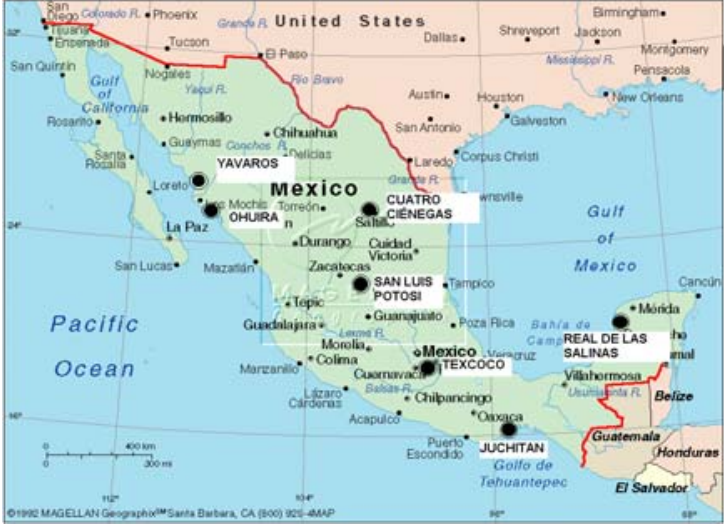

Figure 1

\section{Geographical localization of Artemia strains in Mexico}

Localización geográfica de poblaciones de Artemia en México

\section{Cysts diameter}

Cysts (0.2 g) from each strain were placed in Petri dishes with fresh water for 1 hour until the cysts were fully hydrated (became spherical); one hundred cysts were measured with an Olympus optical microscope equipped with a digital camera and an automated imageanalyzer program.

\section{Diameter of decapsulated cysts}

The hydrated cysts were transferred to a Petri dish and covered with some drops of sodium hypochlorite $(\mathrm{NaOCl})$ to eliminate the chorion (decapsulated). Once decapsulated the cysts were measured with the aforementioned microscope.

\section{Naupliar size}

For each Artemia population, $0.5 \mathrm{~g}$ of cysts was hatched in a 2-L plastic container, with saline water at $35 \mathrm{gL}^{-1}$, temperature of $25 \pm 2^{\circ} \mathrm{C}, \mathrm{pH} 8$, and continuous light and aeration, during $24 \mathrm{~h}$. The hatched nauplii were harvested after $24 \mathrm{~h}$ and a few drops of chloroform were added to immobilize the organisms. One hundred nauplii were measured under the same microscope.

\section{Statistical analysis}

In order to determine the differences in means of the biometric variables measured among populations, analysis of variance (ANOVA) was performed with post hoc Tukey pairwise comparisson test (Montgomery 2004). The statistical significance considered was $\alpha=0.05$. The analysis was performed for hydrated and decapsulated cysts and nauplii as well. Systat version 10.2 statistical package was used for each analysis.

\section{Results}

The biometry results of hydrated and decapsulated cysts, and chorion thickness are shown in Table 2.

The highest value for cyst diameter was obtained from the SLP population $(292.32 \mu \mathrm{m})$ and the smallest from the YAV $(229.20 \mu \mathrm{m})$. ANOVA revealed significant differences among the populations $(P<0.001$, $\mathrm{F}=639.87$; d.f. $=6,693)$, but Tukey's analysis showed no significant differences between the pairs: YAV/C.CIEN $(P=0.802)$ and C.CIEN/TEX $(P=0.994)$. For the diameter of decapsulated cysts, the ANOVA revealed significant differences $(P<0.001, \mathrm{~F}=818.72$; 
Table 2

Mean value of hydrated cysts, decapsulated embryos, and chorion thickness for each Artemia strain studied

Valor promedio de quistes hidratados, embriones descapsulados y grosor de corion de cada una de las poblaciones estudiadas

\begin{tabular}{lccccc}
\hline Population & $\begin{array}{c}\text { Hydrated cyst } \\
\text { diameter } \\
(\mu \mathrm{m})\end{array}$ & $\begin{array}{c}\text { S.D. } \\
(\mu \mathrm{m})\end{array}$ & $\begin{array}{c}\text { Decapsulated cyst } \\
\text { diameter } \\
(\mu \mathrm{m})\end{array}$ & $\begin{array}{c}\text { S.D. } \\
(\mu \mathrm{m})\end{array}$ & $\begin{array}{c}\text { Chorion thickness } \\
(\mu \mathrm{m})\end{array}$ \\
\hline YAV & $229.20 \mathrm{a}$ & \pm 8.97 & $211.67 \mathrm{a}, \mathrm{b}$ & \pm 11.38 & 8.76 \\
OHUI & 266.33 & \pm 8.65 & 250.50 & \pm 25.05 & 7.91 \\
JUCH & 275.52 & \pm 13.07 & 258.91 & \pm 12.95 & 8.30 \\
R.SAL & 249.21 & \pm 8.13 & 229.26 & \pm 9.87 & 9.98 \\
C.CIEN & $231.17 \mathrm{a}, \mathrm{b}$ & \pm 4.39 & $212.87 \mathrm{a}, \mathrm{c}$ & \pm 7.02 & 9.15 \\
SLP & 292.32 & \pm 16.18 & 279.47 & \pm 11.40 & 6.43 \\
TEX & $230.23 \mathrm{~b}$ & \pm 4.50 & $212.37 \mathrm{~b}, \mathrm{c}$ & \pm 4.28 & 8.93 \\
\hline
\end{tabular}

Note: Letters indicate no significant difference $(\alpha=0.05)$.

Table 3

Mean value of naupliar length for each of the Mexican Artemia strain studied

Valor promedio de la talla del nauplio de cada población mexicana de Artemia estudiada

\begin{tabular}{lcc}
\hline Population & $\begin{array}{c}\text { Nauplius length } \\
(\mu \mathrm{m})\end{array}$ & $\begin{array}{c}\text { S.D. } \\
(\mu \mathrm{m})\end{array}$ \\
\hline YAV & $389.60 \mathrm{a}$ & \pm 15.30 \\
OHUI & $379.70 \mathrm{a}$ & \pm 19.47 \\
JUCH & 450.31 & \pm 30.69 \\
R.SAL & $465.36 \mathrm{~b}$ & \pm 29.33 \\
C.CIEN & $472.41 \mathrm{~b}$ & \pm 26.96 \\
SLP & $417.92 \mathrm{c}$ & \pm 23.30 \\
TEX & $422.62 \mathrm{c}$ & \pm 29.00 \\
\hline
\end{tabular}

Letters indicate no significant differences among the populations

d.f = 6,693), whereas Tukey's analysis indicated no significant differences in YAV/C.CIEN $(P=0.973)$; YAV/TEX $(P=0.999)$, and C.CIEN/TEX $(P=1.000)$ pairs.

The mean length of instar I nauplii for each population is given in Table 3 . The highest value was scored for C.CIEN $(472.41 \mu \mathrm{m})$ whiles the lowest for OHUI $(379.70 \mu \mathrm{m})$.

The ANOVA for naupliar length indicated significant differences among populations $(P<0.001, \mathrm{~F}=201.06$, d.f. $=6,693)$. Tukey's test revealed no significant differences between YAV/OHUI $(\mathrm{P}=0.086)$, R.SAL/C.CIEN $(P=0.441)$, and SLP/TEX $(P=0.849)$.

\section{Discussion}

The results presented herein will be instrumental to place the seven Artemia franciscana populations from Mexico in the international context, where information on cysts, nauplii, and adults from different species of the Artemia genus is available (Vanhaecke \& Sorgeloos 1980). Analysis of the present results indicate that the diameter interval of the cysts from the seven studied populations is different when compared to the two most studied Artemia franciscana populations of the American Continent and which are used as reference in the scientific work on A. franciscana; these are the Great Salt Lake (GSL) and San Francisco Bay (SFB) populations. The TEX population is the most similar in terms of cyst diameter (225.7 to $234.7 \mu \mathrm{m}$ ) to the BSF cysts (222.8 to $252.0 \mu \mathrm{m}$ ) (Cowgill et al. 1987), this is because the latter is its progenitor, as it was introduced to the Texcoco lake in 1975 (Castro 1993). The cysts from YAV and OHUI, which are nearby located places, present measures within the intervals measured in the GSL and SFB; YAV with 220.23 to $238.17 \mu \mathrm{m}$ and for OHUI values go from 257.68 to $274.98 \mu \mathrm{m}$ and those of GSL (239.5 a $265.0 \mu \mathrm{m})$ (Vanhaecker \& Sorgeloos 1980) and SFB (222.8 a $252.0 \mu \mathrm{m})$ (Cowgill et al. 1987), being the ones with the smallest diameters. Cysts from JUCH (262.5 to $288.6 \mu \mathrm{m})$ are larger than those from GSL and SFB; R.SAL like JUCH are located in the south of Mexico but in different littorals and their cysts range from 241.1 to $257.3 \mu \mathrm{m}$. The diameter of the C.CIEN cysts $(226.8$ and $235.6 \mu \mathrm{m})$ is similar to that of the TEX, both being from interior waters. The population that is completely outside comparison ranges is that from SLP (276.1 and $308.5 \mu \mathrm{m})$. 
When comparing the cysts values of the Mexican populations with other $A$. franciscana populations from the Americas, it can be observed that except for the population of Macau, Brazil (226.9 to $232.5 \mu \mathrm{m}$ ); the populations from Salinas Bay, Puerto Rico $(253.7 \mu \mathrm{m})$; Chaplin Lake, Canada (240.0 $\mu \mathrm{m})$; Galera Zamba, Colombia $(249.9 \mu \mathrm{m})$ (Vanhaecke \& Sorgeloos 1980); Las Cumaraguas, Venezuela (238.4 $\mu \mathrm{m})$ (Álvarez \& Sánchez 1994) and Yallash, Jamaica (238.5 $\mu \mathrm{m})$ (Castro et al. 2000a), present higher values than the YAV population (229.2 $\mu \mathrm{m})$, which, as aforementioned, presents very similar measurements to those of SFB and Macau, Brazil; both reported as the American population with the smallest cysts. In contrast, in Mexico there is the San Luis Potosí population that produces the largest cysts $(292.3 \mu \mathrm{m})$ among all the above cited populations.

It is observed that the diameter of the decapsulated cysts of the seven populations retain the same relation as the hydrated cysts

Regarding nauplii, the populations with the smalles size are YAV (374.3 to $404.9 \mu \mathrm{m}$ and OHUI (360.2 to $399.2 \mu \mathrm{m})$, and are, therefore attractive to be used in aquaculture. The TEX nauplii (393.6 to $451.6 \mu \mathrm{m}$ ) are smaller than the SFB $(407.3$ and $454.7 \mu \mathrm{m})$ and GSL (459.8 and $518.2 \mu \mathrm{m}$ ). The remaining populations present a larger sized nauplius than the above mentioned Mexican populations, however, their size is within the larger intervals of the GSL population, which is the most marketed in the Western hemisphere. This information allows comparing these seven Mexican populations with those internationally reported and, in particular, with those of the same species in the American Continent.

Regarding naupliar size, three population groups can be formed: YAV/OHUI, very closely located geographically; R.SAL/C.CIEN, distant populations; and SLP/TEX, both from interior waters. It must be pointed out that the JUCH population depicts significant differences with respect to the other populations.

Regarding the other populations cited above, it can be stated that the Mexican nauplii are within the range of the Artemia franciscana species located throughout the American Continent (Vanhaecke \& Sorgeloos 1980, Álvarez \& Sánchez 1994, Castro et al. 2000b).

When comparing the size of the Mexican nauplii with that of other populations from Latin America it can be observed that the nauplii from Venezuela (Alvarez \& Sánchez 1994), (438.69 $\mu \mathrm{m})$ are only similar to the JUCH population $(450.31 \mu \mathrm{m})$; nauplii from Yallash, Jamaica $(427 \mu \mathrm{m})$ (Castro et al. 2000a) present similar intervals to those depicted by the TEX population $(422.62 \mu \mathrm{m}$ ); the Chilean populations (Amat et al. 1994, Zuñiga et al. 1999) (395.50 to $451.70 \mu \mathrm{m}$ ) are similar to the nauplii from JUCH, SLP, and TEX.

Based on the aforementioned and considering the data obtained in this work, it is feasible to use the nauplii from the Mexican TEX, SLP, YAV, and OHUI Artemia populations for feed in both fishes and crustaceans, since their sizes are below $431 \mu \mathrm{m}$, whereas the nauplii from the JUCH, C. CIEN, and R. SAL populations, because of the bigger sizes, can be used for crustacean larvae, but can also be used to feed fish fingerlings, which are in a more advanced developmental stage and, therefore, accept larger-sized feed.

On the other hand, it is advisable to promote the culture of TEX, SLP, YAV, and OHUI Artemia populations, which for their size would serve as food, especially, for ornate fish larvae or crustacean and fishes to be used for human consumption that are cultivated in Mexico.

\section{Literature cited}

Alvarez Z \& R Sanchez. 1994. Evaluation of the quality of the stump of Artemia The Cumaraguas, Paraguayan, Venezuela. Ciencias Marinas 20: 287-299.

Amat F, F Hontoria, O Zúñiga \& R Wilson. 1994. Localización y caracterización de poblaciones chilenas del crustáceo Artemia. Memorias del VIII Congreso Latinoamericano de Acuicultura y V Seminario Nacional de Acuicultura. "Acuicultura y Desarrollo Sustentable", pp. 84-99. Santa Fe de Bogotá, Colombia.

Browne RA \& ST Bowen. 1991. Taxonomy and population genetics of Artemia. In: Browne RA, P Sorgeloos \& CAN Trotman (eds). Artemia Biology 9: 221-235. CRC Press, Mouth Mouse, Florida.

Cámara, MR. 2004. Is small-scale Artemia farming a sustainable alternative to brine shrimp harvesting in Brazilian saltworks? In: Naser A \& P Sorgeloos (eds). International Workshop on Artemia, Urmia, Irán. Pp. 3839. INCO-DEV Project on Artemia Biodiversity (ICA4CT-2001-10020). 
Castro BT. 1993. Biología y cultivo de Artemia franciscana en el Ex Lago de Texcoco, de Ecatepec, Estado de México. PhD. Dissertation. Facultad de Ciencias, Universidad Nacional Autónoma de México, 72 pp.

Castro BT, MG Castro, MJ Castro \& AR De Lara. 1997a. Características morfométricas y calidad de los quistes de Artemia sp. (Crustacea: Anostraca), habitante de aguas sulfatadas de Coahuila, México. Ciencias Marinas 23: 491-503.

Castro BT, MJ Castro, MG Castro \& B Miramontes. 2003. Microelements in nauplii of Artemia franciscana (Kellog, 1906) from six Mexican populations and their relationship with fishes and crustaceans. Hidrobiológica 13: 317-320.

Castro BT, MJ Castro, VRE Marin, GR Young, D Jenoure, MG Castro, SA Malpica \& AR De Lara. 2000a. Calidad de los quistes y morfometria de la población de Artemia franciscana (Kellog, 1906) de la Laguna Pequeña de Yallahs, Jamaica. Ciencias Marinas 26: 201-214.

Castro MG, MJ Castro, AR De Lara, RC Gallardo, CI Salazar, \& B Sánchez. 1989. Características biométricas generales, modo de reproducción y aislamiento reproductivo de la población silvestre de Artemia sp. de Las Salinas de Hidalgo, San Luis Potosí. Revista Latinoamericana de Acuicultura 39: 18-25.

Castro MJ 2004. Caracterización morfométrica y reproductiva (hibridación) de siete poblaciones de Artemia franciscana en México, en relación a su hábitat y latitud. M. Sc. Thesis. Universidad Autónoma Metropolitana Iztapalapa, Mexico, $116 \mathrm{pp}$.

Castro MJ, SA Malpica, MG Castro, BT Thalía \& AR De Lara. 1999. Variación del patrón reproductivo de dos poblaciones mexicanas de Artemia franciscana (Branchiopoda: Anostraca) y su comparación con la población de Bahía de San Francisco, California. Revista de Biología Tropical 47(Supl. I): 99-104.

Castro MJ, SA Malpica, GC Bravo, MG Castro, AR De Lara \& BT Castro. 1997b. Morfometría de la población de Artemia franciscana de Bahía de Ceuta, Sinaloa, México. Oceanología 2:155-167.

Castro MJ, SA Malpica, CJ López, MG Castro, BT Castro \& De Lara AR, 1997c. Evaluación morfométrica de la población de Artemia franciscana de Yavaros, Sonora. Oceanología 1: 143-153.

Castro MJ. SA Malpica, GSA Rodríguez, BT Castro \& AR De Lara. 1995. Análisis morfométrico de Artemia spp. en las salinas "Las Coloradas”, Oaxaca, México. Oceanología 2: 116-128.

Castro T, G Castro \& R De Lara. 1987a. Experimental production of an introduced Artemia strain in alkaline waters in the State of Mexico. In: Sorgeloos P, DA Bengston, W Decleir \& E Jaspers (eds). Artemia research and its applications Vol. 3 Ecology, culturing, use in aquaculture, pp. 319-325. Universa Press, Wetteren, Belgium.

Castro T, A Malpica, J Castro, G Castro \& R De Lara. 2000b. Environmental and biological characteristics of Artemia ecosystems in Mexico: An updated review. In: Munawar M, SG Lawrence, IF Munawar \& DF Malley (eds). Aquatic ecosystems of Mexico. Status and Scope. pp. 191-202. Backhuys Publishers, Leiden, The Netherlands.

Castro T, L Sánchez \& R De Lara. 1987b. Natural sources of brine shrimp (Artemia) in Mexico. In: Sorgeloos P, DA Bengston, W Decleir \& E Jaspers. (eds). Artemia research and its applications. Vol.3 Ecology, culturing, use in aquaculture, pp. 153-159. Universa Press, Wetteren, Belgium.

Cowgill UM, HW Emmel, GU Boggs, PG Murphy, FM Gersich, IT Takahashi \& DA Bengtson. 1987. Variations in chemical composition of Artemia cysts from three geographical locations. In: Sorgeloos P, Bengtson, DA, W Decleir \& E Jaspers (eds). Artemia Research and its Applications. 1. Morphology, Genetics, Strains Characterization, Toxicology, pp. 173-188. Universa Press, Wetteren, Belgium.

Dhont J \& P Sorgeloos. 2002. Applications of Artemia. In: Abatzopoulos TJ, JA Beardmore, JS Clegg \& P Sorgeloos (eds). Artemia basic and applied biology, pp. 251-277. Klüwer Academic Publishers, The Netherlands.

Gallardo C \& MJ Castro.1987. Reproduction and genetics of Mexican Artemia. In: P Sorgeloos, DA Bengston, W Decleir \& E Jaspers (eds). Artemia Research and its Application. Vol. 1. Morphology, Genetics, Strain characterization, Toxicology, pp. 249-253. Universa Press, Wetteren, Belgium.

Léger P, DA Bengston, KL Simpson \& P Sorgeloos. 1986. The use and nutritional value of Artemia as a food source. Oceanography and marine biology: an annual review 24: 521-623.

Malpica SA. 2002. Estructura y composición química de los quistes de Artemia franciscana de diferentes poblaciones mexicanas. M. Sc. Thesis. Universidad Nacional 
Autónoma de México. Facultad de Ciencias, Mexico, 52 pp.

Merchie G. 1996. Manual on the production and use of live food for aquaculture. In: Lavens P \& P Sorgeloos (eds). Cap. 4.3: Use of nauplii and meta-nauplii. FAO Fisheries Technical Paper 361. Rome, Italy.

Montgomery CD. 2004. Introduction to statistical quality control. John Wiley \& Sons, Inc. Publisher Hoboken, USA. 677 pp.

Persoone G \& P Sorgeloos. 1980. General aspects of the ecology and biogeography of Artemia. In: Persoone G, P Sorgeloos, O Roels \& E Jaspers (eds). The brine shrimp Artemia Vol. 3. Ecology, culturing, use in aquaculture, pp. 3-24. Oxford University Press. New York, USA.

Triantaphyllidis GV, TJ Abatzopoulos \& P Sorgeloos. 1998. Review of the biogeography of the genus Artemia (Crustacea, Anostraca). Journal of Biogeography 25: 213226.

Triantaphyllidis GV, GRJ Criel, TJ Abatzopoulos \& P Sorgeloos. 1997a. International study on Artemia. LIV. Morphological study of Artemia with emphasis to Old World strains. I. Bisexual populations. Hydrobiologia 357: 139-153.

Triantaphyllidis GV, GRJ Criel, TJ Abatzopoulos \& $\mathbf{P}$ Sorgeloos. 1997b. International study on Artemia. LIV.
Morphological study of Artemia with emphasis to Old World strains. II. Parthenogenetic populations. Hydrobiologia 357: 155-163.

Van Stappen G. 1996. Manual on the production and use of live food for aquaculture. In: Lavens P \& P Sorgeloos (eds). Chapter 4.2: Use of cysts, pp. 107-136. FAO Fisheries Technical Paper 361. Rome, Italy.

Van Stappen G. 2002. Chapter IV. Zoogeography. In: Abatzopoulos TJ, JA Beardmore, JS Clegg \& P Sorgeloos. (eds). Artemia basic and applied biology, pp. 171-224. Klüwer Academic Publishers, The Netherlands.

Vanhaecke $\mathbf{P}$ \& $\mathbf{P}$ Sorgeloos 1980. International Study on Artemia IV. The biometrics of Artemia strains from different geographical origins. In: Persoone G, P Sorgeloos, O Roels \& E Jaspers (eds) The Brine Shrimp Artemia. Vol. 3. Ecology. Culturing. Use in Aquaculture, pp. 393-405. Universa Press, Wetteren, Belgium.

Vinatea LA. 1999. Manual de producción de Artemia (quistes y biomasa) en módulos de cultivo. División de Ciencias Biológicas. Universidad Autónoma Metropolitana, 47 pp.

Zúñiga O, $R$ Wilson, F Amat \& F Hontoria. 1999. Distribution and characterization of Chilean populations of the brine shrimp Artemia (Crustacea, Branchiopoda, Anostraca). Internacional Journal Salt Lake Research 8: 23-40.

Recibido el 7 de abril de 2006 y aceptado el 28 de agosto de 2006 